\title{
Anton Rochniak
}

Teacher of the Department of Physical Education, National Technical University

"Kharkiv Polytechnic Institute", Kharkiv, Ukraine

E-mail: rochniak15@ukr.net

\section{PSYCHOLOGICAL FEATURES OF MENTAL STATES' SELF-REGULATION OF YOUNG BASKETBALL PLAYERS}

\begin{abstract}
The article reviews features of mental states dynamics of young basketball players before, during and after competitions in connection with various indicators of sports activity self-regulation. It also contains the statistical analysis results of functional states indicators comparisons between groups with different self-regulation of sports activity. It was shown that the nature of changes in the functional state and its peculiarities in the young basketball players is determined by indicators of sports self-regulation.
\end{abstract}

Key words: mental state, self-regulation, functional state, young basketball players, state of health, activity, mood, dynamics.

\section{Антон Рочняк}

викладач кафедри фізичного виховання, Національний технічний університет

"Харківський політехнічний інститут", Харків, Україна

E-mail: rochniak15@ukr.net

\section{ПСИХОЛОГІЧНІ ОСОБЛИВОСТІ САМОВРЯДНОГО РЕГУЛЮВАННЯ МОЛОДИХ БАСКЕТБОЛІСТІВ}

\begin{abstract}
Анотація: У статті розглядаються особливості динаміки психічних станів молодих баскетболістів до, під час та після змагань у зв'язку з різними показниками саморегуляиії спортивної активності. Дослідження містить результати статистичного аналізу порівняльних показників функціональних станів між групами з різною саморегуляцією спортивної активності. Показано, щзо характер змін у функціональному стані та його особливості у молодих баскетболістів визначаються показниками спортивної саморегуляції.
\end{abstract}

Ключові слова: Ключові слова: психічний стан, саморегуляція, функиіональний стан, молоді баскетболісти, стан здоров'я, активність, настрої, динаміка

\section{Антон Рочняк}

\section{ПСИХОЛОГИЧЕСКИЕ ОСОБЕННОСТИ САМОУПРАВЛЯЮЩЕГО РЕГУЛИРОВАНИЯ МОЛОДЫХ БАСКЕТБОЛИСТОВ}

Аннотация: В статье рассматриваются особенности динамики психических состояний молодых баскетболистов до, во время и после соревнований в связи с различными показателями саморегулящии спортивной активности. Исследование содержит результаты статистического анализа сравнительных показателей функииональных состояний между группами с разной саморегулящией спортивной активности. Показано, что характер изменений в функииональном состоянии и его особенности у молодых баскетболистов определяются показателями спортивной саморегуляции.

(C) Anton Rochniak, 2018 
Ключевые слова: психическое состояние, саморегуляция, функциональное состояние, молодежи баскетболисты, состояние здоровья, активность, настроения, динамика.

\section{Антон Рочняк}

Розширена анотація для ознайомлення з цією темою:

\section{“ Психологічні особливості самоврядного регулювання молодих баскетболістів”}

Постановка проблеми. Сьогодні людям доводиться стикатися з величезною кількістю несприятливих чинників, які так чи інакше впливають на їх психічну сферу, що може спровокувати появу негативного психічного стану. Невміння людини регулювати свій стан з використанням внутрішніх механізмів може спричинити негативний вплив на багато аспектів ї̈ життя: взаємини з оточуючими, якість виконання своїх обов'язків, стан здоров'я тощо. Тому психічні стани $і$ їх саморегулячія для сучасного суспільства, яке має дуже високі темпи розвитку, є актуальною психологічною проблемою.

Аналіз останніх досліджень $\boldsymbol{i}$ nyблікацій. Аналіз наявних в літературі визначень психічного стану підкреслюе складність, багатокомпонентний $i$ багаторівневий характер даного феномена.

Добре виклав причину, через яку теорія про психічні стани є слабо опращьованою, О.О. Прохоров і пов'язав проблему визначення психічних станів з самою природою даного феномена, який займає проміжне положення між психічними процесами i психічними властивостями. Це створює методологічні труднощі при вивченні явища, оскільки існує розмитість і відносність кордонів, за якими можна було б ідентифікувати психічний стан.

Проблема психічних станів піднімається в контексті однієї з основних властивостей особистості людини - саморегуляиії.

Серед зарубіжних психологів проблематиџі саморегуляиії приділяли увагу E. Десі у кониепиіiі самодетермінації, $A$. Бандури у теорії самоефективності, P. Бауместейстера у моделі сили ресурсів тощуо. Теорія самодетерміначї Е. Десі та Р. Райана передбачає існування чотирьох типів регулювання діяльності - інтринсивне, екстринсивне, інтроектоване та ідентифіковане.

Формулювання мети статті. Метою дослідження було вивчення особливостей функиіональних станів юних баскетболістівів до, під час та після змагань в залежності від типу саморегуляиії.

Виклад основного матеріалу дослідження. $B$ результаті кластерного аналізу методом К-середніх за показниками саморегуляиії спортивної діяльності було виділено чотири групи. Вони отримали назви: «помірна спортивна саморегуляиіяя», «низька спортивна саморегуляція», «автономна спортивна саморегулячія» та «комбінована спортивна саморегуляиія». Аналіз показників функиіональних станів до, під час та після змагань проводився відповідно до циих чотирьох кластерів.

До змагань не було встановлено статистично значущзих відмінностей між кластерами за жодним з показників функціонального стану.Таким чином, до гри юні баскетболісти оиінюють свій стан приблизно однаково, незалежно від рівня та характеристик спортивної саморегуляиії.

Встановлені статистично значущзі відмінності функиіонального стану під час змагань вказують на те, щуо більш високі показники самопочуття, активності та настрою під час гри пов'язані з високим рівнем ідентифікованого та внутрішнього регулювання та низькими показниками зовнішнього та інтроектованого регулювання, які $\epsilon$ характеристиками групи «автономна спортивна саморегуля- 
ція». Більш низькі показники функціонального стану спортсменів характеризують групи за кластерами 2 «низька спортивна саморегулячія» та 1 «помірна спортивна саморегуляиія».

Ці результати вказують на те, щзо змагальна активність найбільше стимулює функиіональний стан юних баскетболістів групи «автономна спортивна саморегулячія», щзо співпадає з характером цьього профілю, оскільки діяльність ичих юнаків регулюється внутрішнім спонуканням до самої діяльності та до результатів, які вони отримують від неї.

Після змагань також встановлено статистично значущі відмінності між кластерними профілями саморегуляиії.

Результати порівнянь показників функціональних станів до та під час змагань вказують на те, щзо юні баскетболісти 1 і 2 кластерів не налаштовують свій функиіональний стан на змагання. Під час гри вони оцінюють свій функиіональний стан приблизно так само, як і до початку змагань. Кластери 3 i 4, навпаки, значно підвищують свої показники функиіонального стану під час гри, щзо проявляється в крамій самооиінці їхнього стану.

Результати порівнянь показників функціональних станів під час та після змагань вказують на те, щэо у всіх груп

Problem setting. Today, people have to face a huge number of unfavorable factors that somehow affect their psychic sphere and can provoke the emergence of an unfavorable mental state. Inability of people to regulate their mental state using internal mechanisms can have a negative impact on many aspects of their lives: relationships, the quality of their duties, health status, etc. Therefore, mental states and their self-regulation for modern society, that has a very high rate of development, is a particularly relevant psychological problem.

Despite the fact that the mental state is one of the basic concepts of psychology, this category remains poorly understood and little developed. Many scientists note the need for саморегуляиії спостерігається зниження показника "активності", крім кластеру 2, та зменшення показника "самопочуття", щзо обумовлено втратою як фізичної, так i психічної енергіï. У кластерів 3 та 4 всі показники функціонального стану змінюються статистично більш значущо, окрім показника настрою, який не змінюється в 3 кластері.

Висновки з даного дослідження. Найбільш помітною $є$ динаміка показників функціональних станів юних баскетболістів з автономною спортивною саморегуляцією, тобто такі юнаки краще, ніж інші, регулюють свій стан. Це проявляється в тому, щзо вони, перебуваючи в приблизно однаковому стані з усіма іншими групами перед проведенням змагань, можуть підняти показники функиіонального стану на змаганні. Також такі юні баскетболісти мають значні зміни у стані після змагань. В иілому існують значні відмінності між юними баскетболістами з різними видами спортивної саморегуляиії в динамічі та особливостях функиіональних станів до, під час та після змагань. Таким чином, можна стверджувати, щзо характер змін у функціональному стані та його особливості у молодих баскетболістів визначаються показниками спортивної саморегуляиіі.

additional analysis and description of many aspects of the theory of mental states.

Recent research and publications analysis. The literature analysis of the mental state' definitions shows the complexity, multicomponent and multilevel character of this phenomenon. As Ye.S. Rybnikova notes: "These features of mental states make them difficult to access for psychological study and explain the existing difficulties in the development and construction of general psychological theory" [10, p. 116].

Also, today in psychology there is a problem of differentiation of mental states and other phenomena, describing the state of a person from different angles. Ye.S. Rybnikova thinks that the greatest dif- 
ficulties arise in differentiating mental and emotional states, feelings and emotions [10].

Well described the reason why the theory of mental states is poorly worked out by O.O. Prokhorov He linked this problem with the very nature of this phenomenon, which takes as if the intermediate position between mental processes and mental properties. This creates a methodological difficulty in the study of the phenomenon, since there is a blurriness and the relativity of the boundaries that could be used to identify the mental state. Also O.O. Prokhorov, like other scholars, stressed the multilevel, multicomponent, polyfunctional character of mental states and a wide range of their manifestations, which also creates theoretical and methodological difficulties of their study [7].

According to the I.V. Gerasimova: "in the context of one methodological tradition, the mental state is defined as the background for the course of all psychic phenomena, within the other - as an integral characteristic of different systems of the psyche" [4, p.6].

N.D. Levitov defined the mental state as "a holistic characteristic of psychic activity for a certain period of time, which shows the peculiarity of the course of psychic processes, depending on the reflection of objects and phenomena of reality, which preceding the states and psychic properties of the individual" [6, p.20].

O.O. Prokhorov interprets the mental state as "a personality reflection of the situation in the form of a combination (aggregate) of various characteristics of a person arising in the dynamics of psychic activity and expresses the unity of behavior and experience" [8, p.61].

Ye.S. Rybnikova defines mental states as "one of the possible modes of human life, which at the physiological level is characterized by certain energy characteristics, and at the psychological level by a system of psychological filters that provide a specific perception of the world" [9, p.124].

The problem of mental states rises in the context of one of the basic properties of the human personality - self-regulation. As A.B.
Leonova notes, the ability of people to manage their condition is the eternal problem [5].

Analysis of literary sources has shown that the regulation of mental states is carried out in two ways: the prevention of their occurrence and the elimination of already occurring states. Moreover, regulation can be either through the influence on the human psyche from the outside (the influence of a psychologist, the use of color, music, natural landscape), or through self-influence (self-hypnosis, selfbeliefs, self-styles, verbal formulas, changes in muscle tone, regulation of breathing). The second case represents the methods of selfregulation.

Among foreign psychologists, the problems of self-regulation was developed by E. Deci in the concept of self-determination [3], A. Bandura in the theory of self-efficacy [1], R. Baumeister in the strength model of self-control [2] etc. The theory of selfdetermination by E. Deci and R. Ryan suggests the existence of four types of activity regulation - external, introjected, identified and intrinsic.

Unresolved issues of the common problem. The problem of mental states remains inadequately studied in the context of sports activities, in particular the dynamics of the mental states of young basketball players in connection with their specific features of the system of self-regulation.

Paper objective. The purpose of the research was to examine peculiarities of functional states of young basketball players before, during and after the competition depending on the type of self-regulation.

Paper main body. The present research has demanded to apply the following psychodiagnostic methods: 1) "Selfregulation of sport activity Questionnaire" (Fomenko \& Poliluieva, 2017); 2) "State of health , activity, mood" (Doskyn, Lavrent'eva, Sharaj \& Myroshnykov, 1973).

According to the objective of the study, we have examined the typological features of sport self-regulation (fig.1) and their relation with functional states of young bas- 
ketball players before, during and after competition (tables 1 - 6).

K-Means Cluster Analysis was used to identify relatively homogeneous groups of cases based on the characteristics of sport self-regulation. The results of cluster analysis of the characteristics of sport self-regulation are presented in fig. 1 .

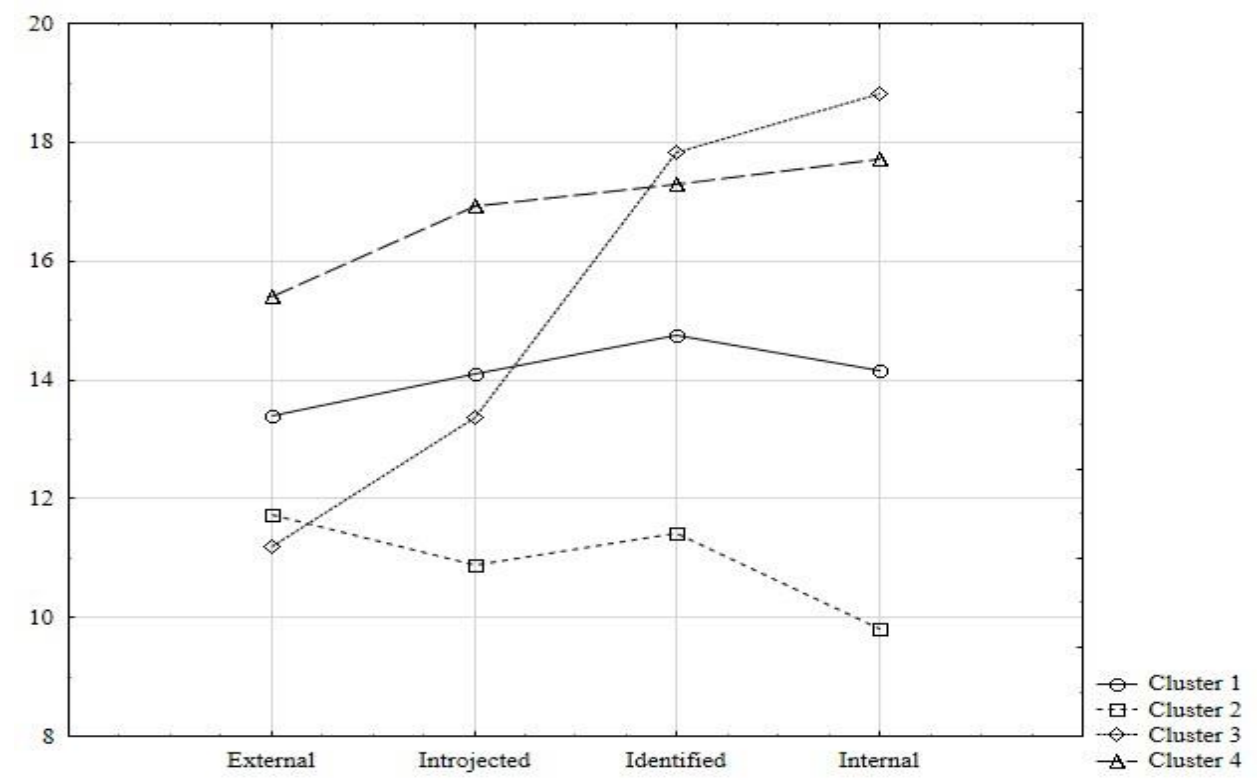

Fig. 1. Cluster profiles resulting from the K-means clustering of sport self-regulation

Cluster 1 was produced by moderate rates of all types of sport-regulation and was labeled as "Moderate sport self-regulation", cluster 2 was produced by low rates of all types of sport-regulation and was labeled as "Low sport self-regulation", cluster 3 was produced by high rates of identified and internal regulation and low rates of external and introjected regulation and was labeled as "Autonomous sport self-regulation", and cluster 4 was produced by high rates of all types of sport-regulation and was labeled as "Combined sport self-regulation".

Kruskal-Wallis ANOVA analysis was used to identify the differences between cluster groups by indicators of functional states and Mann - Whitney U-test was used for pairwise comparison of that groups.

As seen in Table 1, the comparison of four independent groups don't shows statistically significant mean differences in each functional state indicators analyzed in cluster profiles. Thus, until the competition young basketball players evaluate their condition approximately the same, regardless of the level and characteristics of sports selfregulation.

The pair comparison also shows that for any of the functional state indicators are no statistically significant differences between cluster profiles of sports selfregulation.

Table 1 - Indicators of athletes' functional state before the competition

\begin{tabular}{|l|l|l|l|l|l|c|}
\hline \multicolumn{1}{|c|}{ Indicators } & Cluster 1 & Cluster 2 & Cluster 3 & Cluster 4 & H & p \\
\hline State of health & $5,29 \pm 0,09$ & $5,04 \pm 0,13$ & $5,18 \pm 0,12$ & $5,16 \pm 0,1$ & 2,47 & 0,4814 \\
\hline Activity & $4,59 \pm 0,11$ & $4,8 \pm 0,15$ & $4,6 \pm 0,14$ & $4,62 \pm 0,11$ & 0,56 & 0,9049 \\
\hline Mood & $5,11 \pm 0,14$ & $4,87 \pm 0,21$ & $5,01 \pm 0,18$ & $5,08 \pm 0,15$ & 1,94 & 0,5854 \\
\hline Total & $14,99 \pm 0,23$ & $14,7 \pm 0,34$ & $14,8 \pm 0,3$ & $14,85 \pm 0,25$ & 1,76 & 0,6233 \\
\hline
\end{tabular}


Table 2 - Pair comparison of clusters by functional states before the competition

\begin{tabular}{|c|c|c|c|c|c|c|}
\hline \multirow{2}{*}{ Indicators } & \multicolumn{6}{|c|}{$\mathrm{U}, \mathrm{p}$} \\
\hline & I / II & I / III & I / IV & II / III & II / IV & III / IV \\
\hline $\begin{array}{l}\text { State of } \\
\text { health }\end{array}$ & $560 ; 0,15$ & $\begin{array}{c}816,5 ; \\
0,52\end{array}$ & $1130 ; 0,35$ & $\begin{array}{c}373,5 \\
0,4\end{array}$ & 551,$5 ; 0,5$ & $\begin{array}{c}724,5 \\
0,62\end{array}$ \\
\hline Activity & $\begin{array}{c}660,5 \\
0,67\end{array}$ & $809 ; 0,48$ & $\begin{array}{c}1204,5 \\
0,66\end{array}$ & $419 ; 0,88$ & $\begin{array}{c}592,5 \\
0,84\end{array}$ & $\begin{array}{c}738,5 \\
0,72\end{array}$ \\
\hline Mood & $569 ; 0,17$ & $\begin{array}{c}798,5 \\
0,42\end{array}$ & $\begin{array}{c}1260,5 \\
0,96\end{array}$ & $410 ; 0,78$ & $\begin{array}{c}527,5 \\
0,34\end{array}$ & $710 ; 0,53$ \\
\hline Total & $\begin{array}{c}593,5 \\
0,27\end{array}$ & $\begin{array}{c}781,5 \\
0,34\end{array}$ & $1173 ; 0,52$ & $409 ; 0,77$ & $\begin{array}{c}556,5 \\
0,53\end{array}$ & $\begin{array}{c}717,5 \\
0,57\end{array}$ \\
\hline
\end{tabular}

The comparison of four independent indicators, the cluster 3 has the highest groups shows statistically significant mean average, while the lowest values has cluster differences in each indicator of functional 2 . state during the game (table 3 ). For all of the

Table 3 - Indicators of athletes' functional states during the competition

\begin{tabular}{|l|c|c|c|c|c|c|}
\hline \multicolumn{1}{|c|}{ Indicators } & Cluster 1 & Cluster 2 & Cluster 3 & Cluster 4 & H & $\mathrm{p}$ \\
\hline State of health & $5,12 \pm 0,09$ & $4,85 \pm 0,13$ & $5,72 \pm 0,12$ & $5,4 \pm 0,1$ & 18,63 & 0,0003 \\
\hline Activity & $4,76 \pm 0,12$ & $4,76 \pm 0,18$ & $5,91 \pm 0,16$ & $5,47 \pm 0,13$ & 34,9 & 0,0000 \\
\hline Mood & $5,14 \pm 0,11$ & $4,91 \pm 0,16$ & $5,93 \pm 0,15$ & $5,53 \pm 0,12$ & 23,09 & 0,0000 \\
\hline Total & $15,03 \pm 0,25$ & $14,52 \pm 0,36$ & $17,56 \pm 0,32$ & $16,4 \pm 0,27$ & 40,63 & 0,0000 \\
\hline
\end{tabular}

Table 4 - Pair comparison of clusters by functional states during the competition

\begin{tabular}{|c|c|c|c|c|c|c|}
\hline \multirow{2}{*}{ Indicators } & \multicolumn{6}{|c|}{$\mathrm{U}, \mathrm{p}$} \\
\hline & I / II & I / III & $\mathrm{I} / \mathrm{IV}$ & II / III & II / IV & III / IV \\
\hline $\begin{array}{l}\text { State of } \\
\text { health }\end{array}$ & $\begin{array}{l}544 \\
0,11\end{array}$ & $518 ; 0,0011$ & 1115,$5 ; 0,3$ & $\begin{array}{c}180 \\
0,00015\end{array}$ & $\begin{array}{c}399 \\
0,015\end{array}$ & $\begin{array}{c}541,5 ; \\
0,022\end{array}$ \\
\hline Activity & 701,$5 ; 1$ & $\begin{array}{c}310 ; \\
0,00000038\end{array}$ & $\begin{array}{c}728 ; \\
0,00023\end{array}$ & $\begin{array}{c}163 ; \\
0,00005\end{array}$ & $\begin{array}{c}367 \\
0,005\end{array}$ & $\begin{array}{l}550,5 \\
0,028\end{array}$ \\
\hline Mood & $\begin{array}{c}590,5 \\
0,25\end{array}$ & 440,$5 ; 0,000083$ & 927,$5 ; 0,02$ & $\begin{array}{c}188 \\
0,00024\end{array}$ & $\begin{array}{l}381,5 ; \\
0,0083\end{array}$ & $\begin{array}{c}553,5 \\
0,03\end{array}$ \\
\hline Total & $\begin{array}{c}606,5 \\
0,33\end{array}$ & $\begin{array}{c}275,5 ; \\
0,000000075\end{array}$ & $\begin{array}{c}777,5 ; \\
0,00083\end{array}$ & $\begin{array}{c}128 ; \\
0,0000045\end{array}$ & $\begin{array}{l}319,5 ; \\
0,0008\end{array}$ & $\begin{array}{l}471,5 \\
0,003\end{array}$ \\
\hline
\end{tabular}

There are statistically significant differences in the "state of health" between all clusters except 1 cluster compared to clusters 2 and 4 (table 4). According to other indicators of the functional state there are statistically significant differences between all clusters except 1 cluster compared to 2 .

Thus, higher rates of state of health, activity and mood during the game are associated with high level of identified and internal regulation and low rates of external and introjected regulation, which are the characteristics of a group with "Autonomous sport self-regulation". Lower rates of functional state indicators of athlete characterize groups by clusters of 2 "Low sport self-regulation" and 1 "Moderate sport self-regulation". Consequently, autonomous 
or self-determined motivation is associated with high level of functional state of athlete during the basketball game.

This indicates that the young basketball players of the 3 cluster assess their condition during the game as a state more full of strength, health and mesh tires, with greater mobility, speed and rate of functions flow and more positive characteristics of the emotional state compared with other young basketball players. The rates of functional state indicators of cluster 2 and 1 are at the lowest level compared to other clusters and are approximately the same which is confirmed by the absence of statistically significant differences between these clusters.

These results indicate that competitive activity most of all stimulates the functional status of the young men of the ACC group, which coincides with the nature of this profile, since the activity of these young men is regulated by the internal motivation to work.

As seen in Table 5, the comparison of four independent groups shows statistically significant mean differences $(p<0,01)$ in each functional state indicators after the competition analyzed in cluster profiles.

Table 5 - Indicators of athletes' functional states after the competition

\begin{tabular}{|l|l|l|l|l|l|c|}
\hline \multicolumn{1}{|c|}{ Indicators } & \multicolumn{1}{c|}{ Cluster 1 } & Cluster 2 & Cluster 3 & Cluster 4 & H & $\mathrm{p}$ \\
\hline State of health & $4,46 \pm 0,12$ & $4,34 \pm 0,18$ & $3,91 \pm 0,16$ & $3,78 \pm 0,13$ & 17,77 & 0,0005 \\
\hline Activity & $4,1 \pm 0,1$ & $4,12 \pm 0,15$ & $3,19 \pm 0,13$ & $3,55 \pm 0,11$ & 27,61 & 0,0000 \\
\hline Mood & $4,94 \pm 0,11$ & $4,92 \pm 0,16$ & $5,68 \pm 0,14$ & $4,99 \pm 0,12$ & 15,78 & 0,0013 \\
\hline Total & $13,5 \pm 0,21$ & $13,39 \pm 0,3$ & $12,78 \pm 0,27$ & $12,32 \pm 0,22$ & 16,21 & 0,0010 \\
\hline
\end{tabular}

According to the average indicators of the functional state after the game cluster 1 and 2 dominated clusters 3 and 4, except for the "mood" indicator, according to which young basketball players with autonomous sports self-regulation have the highest rates.

Table 6 - Pair comparison of clusters by functional states after the competition

\begin{tabular}{|c|c|c|c|c|c|c|}
\hline \multirow{2}{*}{ Indicators } & \multicolumn{6}{|c|}{$\mathrm{U}, \mathrm{p}$} \\
\hline & I / II & I / III & I / IV & II / III & II / IV & III / IV \\
\hline $\begin{array}{l}\text { State of } \\
\text { health }\end{array}$ & $679 ; 0,82$ & $\begin{array}{l}547,5 ; \\
0,0027\end{array}$ & $\begin{array}{l}711 ; \\
0,00015\end{array}$ & $\begin{array}{l}308,5 ; \\
0,067\end{array}$ & $408 ; 0,02$ & $742 ; 0,75$ \\
\hline Activity & $\begin{array}{l}681,5 \\
0,84 \\
\end{array}$ & $\begin{array}{l}409 ; \\
0,000025\end{array}$ & $\begin{array}{l}718,5 ; \\
0,00018\end{array}$ & $\begin{array}{l}204,5 ; \\
0,00063\end{array}$ & $\begin{array}{l}361 ; \\
0,0041\end{array}$ & $\begin{array}{l}647,5 \\
0,21\end{array}$ \\
\hline Mood & $684 ; 0,86$ & $\begin{array}{l}485,5 ; \\
0,0004\end{array}$ & $1248 ; 0,89$ & $\begin{array}{l}231,5 ; \\
0,0026\end{array}$ & $\begin{array}{l}602,5 \\
0,93\end{array}$ & $\begin{array}{l}438,5 \\
0,001\end{array}$ \\
\hline Total & $\begin{array}{l}692,5 \\
0,93\end{array}$ & $678 ; 0,063$ & $\begin{array}{l}671 ; \\
0,000047\end{array}$ & 354,$5 ; 0,26$ & $\begin{array}{l}400,5 \\
0,016\end{array}$ & $649 ; 0,22$ \\
\hline
\end{tabular}

Pair comparison shows statistically significant difference by indicator "state of health" between cluster 1 and clusters 3 , cluster 1 and 4, as well as between 2 cluster and 4 cluster. According to this indicator, moderate and low sports self-regulated young basketball players have higher scores, that is, they feel more full of strength, health, and mesh tired, which may be due to the difference in exhaustion after the game.

According to the "activity" indicator, a statistically significant mean difference was established between the cluster 1 and 2 on the one hand and the clusters 3 and 4 on the other. This indicates that young basketball players with moderate and low sports self-regulation evaluate their condition after the competition as 
a condition with greater mobility, speed and flow rate of functions compared to young basketball players with autonomous and combined sports self-regulation.

According to the "mood" indicator, there are statistically significant mean differences between the 3 cluster and other cluster. Thus, with autonomous sports self-regulation evaluate their functional state after the competition by the characteristics of emotion as more positive compared to other young basketball players.

The results of the statistical analysis of the functional states before, during and after the competition confirm our belief that the level of self-regulation affects the ability to regulate the functional state and the overall difference in the display of indicators before, during and after the competition.

To confirm our opinion, we will analyze the dependent variables, which we will select our indicators of functional state before, during and after the competition among the four clusters.

The Wilcoxon signed-rank test was used to compare two related samples.

There are no statistically significant differences in any indicator of functional state before and during the game in young basketball players with moderate sports selfregulation (table 7).

Table 7 - Comparison of functional states indicators of the cluster 1 before and during the competition

\begin{tabular}{|l|c|c|c|c|}
\hline \multicolumn{1}{|c|}{ Indicators } & Before & During & $\mathrm{T}$ & $\mathrm{p}$ \\
\hline State of health & $5,29 \pm 0,09$ & $5,12 \pm 0,09$ & 610 & 0,47 \\
\hline Activity & $4,61 \pm 0,11$ & $4,95 \pm 0,14$ & 510,5 & 0,31 \\
\hline Mood & $5,1 \pm 0,15$ & $5,05 \pm 0,12$ & 742 & 1 \\
\hline Total & $15 \pm 0,25$ & $15,13 \pm 0,25$ & 710 & 0,96 \\
\hline
\end{tabular}

Thus, young basketball players with moderate sport self-regulation during the competition do not undergo significant changes in the functional state compared to the period before the game.
As seen in table 8 , there are no statistically significant differences in any indicator of functional state before and during the game in young basketball players with low sports self-regulation.

Table 8 - Comparison of functional states indicators of the cluster 2 before and during the competition

\begin{tabular}{|l|c|c|c|c|}
\hline \multicolumn{1}{|c|}{ Indicators } & Before & During & $\mathrm{T}$ & $\mathrm{p}$ \\
\hline State of health & $5,04 \pm 0,13$ & $4,85 \pm 0,13$ & 110,5 & 0,26 \\
\hline Activity & $4,78 \pm 0,16$ & $4,47 \pm 0,2$ & 141 & 0,8 \\
\hline Mood & $4,87 \pm 0,21$ & $4,97 \pm 0,17$ & 171,5 & 0,92 \\
\hline Total & $14,69 \pm 0,35$ & $14,29 \pm 0,36$ & 127 & 0,34 \\
\hline
\end{tabular}

It also indicates that competitive activity does not generally cause changes in the functional state of this group.

There are statistically significant differences in each of functional state indicators before and during the game in young basketball players with autonomous sports selfregulation (table 9). 
Table 9 - Comparison of functional states indicators of the cluster 3 before and during the competition

\begin{tabular}{|l|c|c|c|c|}
\hline \multicolumn{1}{|c|}{ Indicators } & Before & During & T & $p$ \\
\hline State of health & $5,18 \pm 0,12$ & $5,72 \pm 0,12$ & 93 & 0,0014 \\
\hline Activity & $4,6 \pm 0,14$ & $5,95 \pm 0,17$ & 0 & 0,00000054 \\
\hline Mood & $5,01 \pm 0,19$ & $6,01 \pm 0,15$ & 76 & 0,00075 \\
\hline Total & $14,8 \pm 0,31$ & $17,68 \pm 0,32$ & 33 & 0,0000098 \\
\hline
\end{tabular}

Thus, during the competition, such young men evaluate their condition as more full of strength, health and less tired, with more mobility, speed and flow rate of functions and more positive characteristics of emotions compared with the state of the competition. In general, competitive activity calls for changes in their functional state, which in turn is possible due to the developed ability to self-regulation and its peculiarities.

As seen in table 10, there are statistically significant differences in each of functional state indicators before and during the game in young basketball players with combined sports self-regulation.

Table 10 - Comparison of functional states indicators of the cluster 4 before and during the competition

\begin{tabular}{|l|c|c|c|c|}
\hline \multicolumn{1}{|c|}{ Indicators } & Before & During & Z & $\mathrm{p}$ \\
\hline State of health & $5,16 \pm 0,1$ & $5,4 \pm 0,1$ & 277,5 & 0,047 \\
\hline Activity & $4,61 \pm 0,12$ & $5,44 \pm 0,15$ & 165 & 0,000024 \\
\hline Mood & $5,09 \pm 0,16$ & $5,51 \pm 0,13$ & 358,5 & 0,047 \\
\hline Total & $14,86 \pm 0,26$ & $16,36 \pm 0,27$ & 165 & 0,000069 \\
\hline
\end{tabular}

These young basketball players also evaluate their condition as more full of strength, health and less tired, with greater mobility, speed and flow rate of functions and more positive characteristics of emotions compared with the functional state before the competition. But it is noteworthy that the growth in terms of "well-being" and "mood" during the competition is not as statistically significant as in cluster 3 .

In general, we can say that young basketball players of 1 and 2 clusters do not adjust their functional state to the competi- tion. During the game, they evaluate their functional state approximately the same as the state before the competition. Cluster 3 and 4 , on the contrary, significantly increase their indicators of functional state during the game, which manifests itself in a better selfassessment of their condition.

There are statistically significant differences in «state of health» and «activity» indicators of functional state during and after the game in young basketball players with moderate sports self-regulation (table 11).

Table 11 - Comparison of functional states indicators of the cluster 1 during and after the competition

\begin{tabular}{|l|c|c|c|c|}
\hline \multicolumn{1}{|c|}{ Indicators } & During & After & Z & $\mathrm{p}$ \\
\hline State of health & $5,12 \pm 0,09$ & $4,46 \pm 0,12$ & 302 & 0,00025 \\
\hline Activity & $4,95 \pm 0,14$ & $4,1 \pm 0,1 \mathrm{c}$ & 327 & 0,00035 \\
\hline Mood & $5,05 \pm 0,12$ & $4,94 \pm 0,11$ & 562 & 0,25 \\
\hline Total & $15,13 \pm 0,25$ & $13,5 \pm 0,21$ & 302 & 0,00015 \\
\hline
\end{tabular}


Thus, after the competition, the young basketball players of 1 cluster evaluate their condition as less full of strength, health and more tired, with less mobility, speed and flow rate of functions.

As seen in table 12, there are statistically significant differences in «activity» in- dicator of functional state during and after the game in young basketball players with low sports self-regulation. This indicates some tiredness after the competition of this group.

Table 12 - Comparison of functional states indicators of the cluster 2 during and after the competition

\begin{tabular}{|l|c|c|c|c|}
\hline \multicolumn{1}{|c|}{ Indicators } & During & After & Z & $\mathrm{p}$ \\
\hline State of health & $4,85 \pm 0,13$ & $4,34 \pm 0,18$ & 97 & 0,078 \\
\hline Activity & $4,47 \pm 0,2$ & $4,12 \pm 0,15$ & 96,5 & 0,045 \\
\hline Mood & $4,97 \pm 0,17$ & $4,92 \pm 0,16$ & 173 & 0,95 \\
\hline Total & $14,29 \pm 0,36$ & $13,39 \pm 0,3$ & 109 & 0,091 \\
\hline
\end{tabular}

There are statistically significant differences in «state of health» and «activity» the game in young basketball players with indicators of functional state during and after autonomous sports self-regulation (table 13).

Table 13 - Comparison of functional states indicators of the cluster 3 during and after the competition

\begin{tabular}{|l|c|c|c|c|}
\hline \multicolumn{1}{|c|}{ Indicators } & During & After & Z & $p$ \\
\hline State of health & $5,72 \pm 0,12$ & $3,91 \pm 0,16$ & 14 & 0,0000029 \\
\hline Activity & $5,95 \pm 0,17$ & $3,19 \pm 0,13$ & 1 & 0,00000059 \\
\hline Mood & $6,01 \pm 0,15$ & $5,68 \pm 0,14$ & 220 & 0,28 \\
\hline Total & $17,68 \pm 0,32$ & $12,78 \pm 0,27$ & 6 & 0,00000094 \\
\hline
\end{tabular}

Indicators in this group decrease significantly more after the competition compared to the 1 and 2 cluster. Thus, after the competition, such young men evaluate their functional state more neutral, as the average values of the indicators shows, only the mood remains quite high. The absence of differences in the "mood" indicator may indi- cate that the positive emotions of the game remain in them afterwards.

As seen in table 14, there are statistically significant differences in each of functional state indicators during and after the game in young basketball players with combined sports self-regulation.

Table 14 - Comparison of functional states indicators of the cluster 4 during and after the competition

\begin{tabular}{|l|c|c|c|c|}
\hline \multicolumn{1}{|c|}{ Indicators } & During & After & Z & $\mathrm{p}$ \\
\hline State of health & $5,4 \pm 0,1$ & $3,78 \pm 0,13$ & 1 & 0,0000000 \\
\hline Activity & $5,44 \pm 0,15$ & $3,55 \pm 0,11$ & 21,5 & 0,000000014 \\
\hline Mood & $5,51 \pm 0,13$ & $4,99 \pm 0,12$ & 233 & 0,0022 \\
\hline Total & $16,36 \pm 0,27$ & $12,32 \pm 0,22$ & 7 & 0,0000000 \\
\hline
\end{tabular}


All the figures in this group are significantly reduced after the competition. Thus, after competitions such young basketball players generally evaluate their condition more neutral, even the mood decreases more than in cluster 3, which may be associated with higher rates of external and introjected regulation of these athletes.

In general, for all groups of selfregulation there is a decrease in the indicator of "activity" and all clusters except cluster 2 decrease in the "state of health" indicator after the competition, which is conditioned by the loss of both physical and psychic energy. The mood of the cluster 1 and 2 does not change as this indicator was not high during the game. In the cluster 3 and 4, all functional state indicators are changes more statistically significantly except the "mood" indicator, which does not change in cluster 3 . In our opinion, the inhibition of the functional state after the competition is an important mechanism for creating favorable conditions for the restoration of energy and a better objective analysis of their activities.

Conclusions of the research. There are statistically significant differences in the functional state indicators between sports self-regulation groups during and after the competition, although before the competitions there are no statistically significant differences between groups. The most significant difference between the indicators of the functional state is revealed during the competitions, where the group of young basketball players with autonomous sports self-

\section{References}

1. Bandura, A. (1991) Self-regulation of motivation through anticipatory and selfreactive mechanisms, Perspectives on motivation: Nebraska symposium on motivation, Lincoln: University of Nebraska Press, vol. 38, pp. 69-164.

2. Baumeister, R.F., Schmeichel, B.J., Vohs, K.D. (2007) Self-Regulation and executive function: The Self as controlling agent, Social psychology: Handbook of basic regulation has the highest rates among other groups, which testifies to the ability to best regulate and prepare their functional states for the game.

The dynamics of functional states before, during and after competitions in various groups of sports self-regulation is also researched. It is shows that the dynamics of functional states indicators of young basketball players with autonomous sports selfregulation is most noticeable, that is, such young men better than others regulate their condition. This is manifested in the fact that they being in an approximately the same condition with all other groups before the competition, can raise the indicators of functional state for the competition. Also, such young basketball players have more significant changes after the competition. In our opinion, this can be deliberately due to the fact that certain suppression of the functional state after the competition is an important mechanism for creating favorable conditions for the restoration of energy and a better objective analysis of their activities.

In general there are significant differences between young basketball players with different types of sports self-regulation in the dynamics and features of functional states before, during and after the competition. Thus, it can be argued that the nature of changes in the state and its peculiarities in the young basketball players is determined by indicators of sports self-regulation.

principles (2nd ed.), New York: Guilford Press, pp. 516-539.

3. Deci, E., Ryan, R. (2008), Selfdetermination theory: A macro theory of human motivation, development, and health, Canadian Psychology, vol. 49(3), pp. 182185.

4. Herasymova, Y.V. (2001), Psykhycheskye sostoianyia kak obschepsykholohycheskaia problema: Khrestomatyia, Vladyvostok: DVHMA, 104 p. 
5. Leonova, A. B. (2007), Psykholo- sostoianyj: Uchebnoe posobye, M.: Yzd-vo hycheskye tekhnolohyy upravlenyia sosto- «Kohyto-Tsentr», $624 \mathrm{p}$.

ianyem cheloveka, Moskva: Smysl, 311 p.

9. Rybnykova, E.S. (2009), K

6. Levytov, N. D. (1964), O psykhy- probleme dyfferentsyatsyy psykhycheskykh cheskykh sostoianyiakh cheloveka, M.: Pros- y emotsyonal'nykh sostoianyj, Vestnyk veschenye, $344 \mathrm{p}$.

KHPU ym. V.P. Astaf'eva, Krasnoiarsk,

7. Prokhorov, A.O., Habdreeva, H.

Sh. (2004), Praktykum po psykholohyy sostoianyj: Uchebnoe posobye, $\mathrm{SPb}$ : Rech', 480 p. vol.1. pp.123-125.

10. Rybnykova, E.S. (2009), Osnovnye teoretycheskye podkhody $\mathrm{v}$ yzuchenyy psykhycheskykh sostoianyj 8. Prokhorov, A.O., Valyullyna, Vestnyk KHPU ym. V.P. Astaf'eva, M.E., Habdreeva, H.Sh., Haryfullyna, M.M., $\quad$ Krasnoiarsk, vol. 3. pp. 116-119.

Mendelevych, V.D. (2011), Psykholohyia

Стаття надійшла до редколегї: 16.08.2018 